\title{
LATERAL SYNDROME OF THE MEDULLA OBLONGATA (WALLENBERG'S SYNDROME) AS A COMPLICATION
}

\author{
OF A VERTEBRAL ANGIOGRAPHY. A CASE REPORT
}

\author{
Roberto Melaragno *
}

A bibliographic review did not show us a case report similar to the present one in which a medulla oblongata's lateral syndrome (Wallenberg's syndrome) had complicated a vertebral angiography made through direct vessel's puncture.

In the case of Sahadevan and col. ${ }^{23}$ the lateral ischemia of the medulla oblongata in a man 19 years old took place prior to the vertebral angiography and it was precisely the cause of this examination; as a complication following the mentioned angiography, a transient cortical blindness appeared. Incidentally, cortical blindness seems to constitute one of the most frequent complication of vertebral angiography, either by direct puncture of the vertebral vessel or by retrograde route ${ }^{18}$, or by catheterization ${ }^{8,10,14}$; it is interesting to note that visual complications may also follow the angicgraphy by carotid artery (Haney and Preston ${ }^{7}$ ). Other more infrequent forms of complications arising from vertebral angiographies may occur, including direct osteolytic lesion of the vertebral body ${ }^{29}$, myelomalacia of the cervical spinal cord ${ }^{6}$ as well as varied forms of laryngeal involvement. Dobrek and col. ${ }^{5}$ emphazise the possible side effects of angiographies in patients over 50 years.

\section{O B S E R V A T I O N}

I.M.O., a woman 54 years old, Brazilian, nun. Admission on August 2, 1968. in the anamnesis there are references to a symptomatology of a simple diving goiter (October 1967), found out through a chest planigraphy. After surgery, she presented a dysphonia resulting from an involvement of the left recurrent nerve, and approximately at the same time, hallucinatory vision of objects or images at the right fields of vision. Later, these subjective sensations were replaced by nondifferentiated phosphenes and haze, always in the right fields of vision. On February 1st, 1968, a neuro-ophtalmologic examination showed only a right subtotal homonymous hemianopsia; the visual acuity was intact; the pupillary reflexes, extrinsic motricity, ocular pressure, corneal sensibility, eye ground, and ophtalmodynamometry were normal. At the physical examination, slight telangiectasias in the lower limbs were observed. Blood pressure: $170 \times 100$. Neurological examination - Normal gait; muscular strength preserved; Romberg's sign absent; normal coor-

* Head of the Division of Neurology of the Hospital do Servidor Público do Estado de Sãı Paulo, Brazil. 
dination; deep and superficial reflexes, normal. Normal sensibility in all superficial and deep forms. Absence of sensitive phenomena of extinction. Paresis of the left vocal chord. Right homonymous hemianopsia. Electroencephalogram normal. Skull $X-R a y$ normal. Cerebrospinal fluid: suboccipital puncture; initial pressure $20 \mathrm{~cm}^{3}$ of water; 0 cells; proteins $15 \mathrm{mg}$; immunological examinations negative.

On August 4, 1968, the patient was submitted under general anesthesia to a left carotidography with Hypaque as the contrast medium, the posterior cerebral artery beeing not visualized. At the same occasion an angiography through a direct puncture of the vertebral artery was performed, both posterior cerebral arteries being visualized. The puncture of the vertebral artery was imperfect with infiltration of the contrast in the vessel's inner coat (fig. 1). Soon after the patient presented a lateral bulbar syndrome (Wallenberg's syndrome) at the right side (cerebellar syndrome at the right side of the body, hyposthesia with severe right hemifacial pain, delimited at the trigeminal area, alternate hyposthesia involving the right hemiface and the left side of the body, chiefly the upper limb). Still at the right side, a Claude-Bernard-Horner's syndrome and paresis of the palate and, at the lesser grade, of the right vocal chord was observed. The evolution of the case was satisfactory, although the clinical picture was always evidencing neuralgia at the right hemiface, but not presenting the paroxysmal characteristics of the classic trigeminal neuralgia.

\section{O M M E N T S}

This case seems to prove once more that the lateral medulla oblongata's syndrome depends rather on the occlusion of the vertebral artery than on the inferoposterior cerebellar artery, although this latter is directly responsible for the irrigation of the ischemic area. Incidentally, this fact has been reported by many authors during the past years $1,4,12$.

An interesting aspect in this case is in connection with the possible pathogenic mechanism of the complication occurred. Indeed, several mechanisms have been considered responsible for the most varied adverse effects, being in their majority ischemic complications caused by cerebral angiographies. It seems that the mechanism most frequently mentioned would be that representend by incorrect injections ${ }^{3}, 15,21,24,25,26$ sometimes unavoidable, in the vascular wall, with dissection of the coat beneath the intima by the contrast medium. However, other possible mechanisms could also be responsible $^{2}$ : toxic effects of the contrast medium ${ }^{3}$ although there is not a necessary correlation between the volume of the contrast medium and the frequency of complications ${ }^{7}$; aggravation of the ischemia through the temporary replacement of blood by the contrast medium ${ }^{13}{ }^{16}$; hypotension during anesthesia ${ }^{26}$; stricture provoked by the needle itself or catheter; intravascular agglomeration of blood components ${ }^{11},{ }^{16,20}$ interfering with the microcirculation in the tissues, and influence on the normal standard of serum proteins ${ }^{13}$. Complications caused by cerebral angiography would be more frequently in older individuals ${ }^{16,22}$. In accordance with Baker ${ }^{1}, 3$ per cent of patients over sixty years present a reduction of about 50 per cent in the vertebral artery lumen, so that special precautionary steps should be taken when performing an angiography of the vertebral artery in patients over sixty years, because of the risk of an ischemic complication inherent to the 


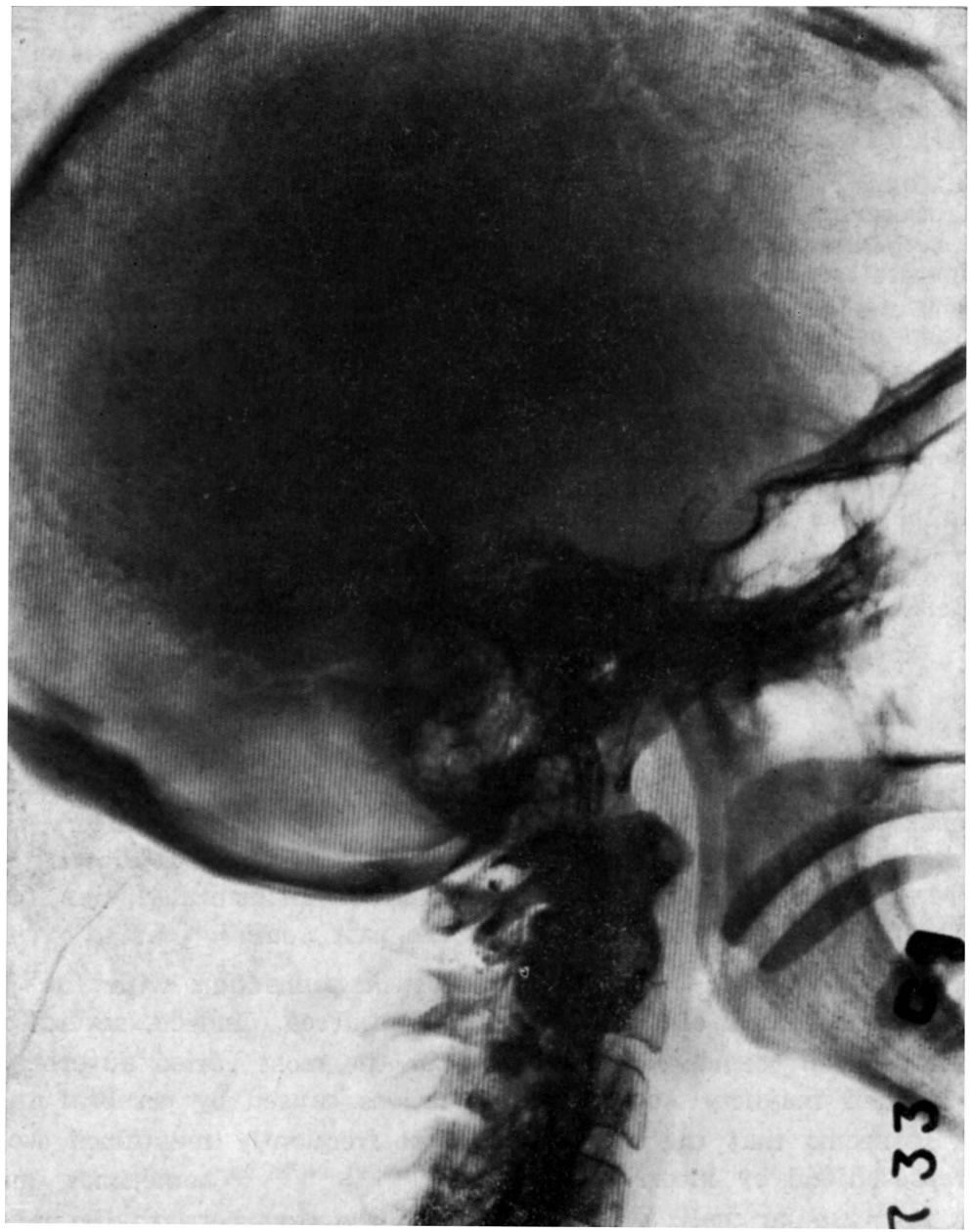

Fig. 1 - Infiltration of the contrast in the inner coat of the vertebral artery.

brain stem. In the casuistics of Petit-Dutaillis and col. ${ }^{19}$ four severe accidents were related, with two deaths in 162 vertebral angiographies.

Anyway, it has been assumed that frequency and severity of complications would be inversely proportional to the distance between the nervous tissue and the site of injection of the contrast medium ${ }^{3}$. Thus, the contrast media injected through catheterization in the extracranial vessels that emerge from the arch of the aorta would be less dangerous than the direct injection into the artery to be visualized. On the other side, the caliber variability (as individual anatomical variations) of the vessels irrigating the brain is well known, mainly for the vertebral artery. Obviously, the 
tentative to puncture this artery, sometimes filiform, causes a greater number of defective injections. We think it is very probable that in the reported case the lesion occurring in the vertebral artery has been provoked by the angiographically verified extravasation of the contrast medium into the vessel wall.

The complication reported constitutes one more warning to avoid the angiography through direct puncture of the vertebral artery which, when necessary, should be visualized throug indirect contrastation, either by retrograde route, through the subclavian or humeral artery, or by catheterization.

\section{S U M M A R Y}

Case report of a female patient, 58 years old, who, due to a right homonymous hemianopsia, was submitted under general anesthesia successively to angiographies through the right carotid and vertebral arteries. At the first examination no abnormalities were evidenced, but the contrast medium did not reach the posterior cerebral artery; angiography by the right vertebral artery, with extravasation of the contrast medium into the vessel wall, visualized both posterior cerebral arteries. Immediately after the angiographic study, the patient presented the characteristic picture of the Wallenberg's syndrome caused by involvement of the right lateral part of the medulla oblongata. The evolution of the case was good, despite the residual right hemifacial neuralgic pain. An involvement of the vertebral artery, through an intramural injection of Hypaque is assumed to be the most probable pathogenic mechanism. The reported complication is considered as one more warning to prevent angiographies of the vertebral artery through direct puncture of this vessel, due to its recognized anatomical variations.

Sindrome lateral do bulbo (Wallenberg) como complicação de angiografia pela artéria vertebral.

Registro do caso de uma mulher, de 58 anos de idade que, por apresentar hemianopsia homonima direita, foi submetida, sob anestesia geral, sucessivamente, a angiografias, pelas artérias carótida e vertebral direitas. Ao primeiro exame não se evidenciou qualquer anormalidade, mas o contraste não atingiu a artéria cerebral posterior; a angiografia pela artéria vertebral direita, com estravazamento do contraste na parede vascular, visualizou ambas as artérias cerebrais posteriores. Imediatamente após o estudo angiográfico, a paciente apresentou o quadro característico da síndrome de Wallenberg, causada pelo comprometimento da porção lateral direita do bulbo. A evolução do caso foi satisfatória, a despeito da dôr nevrálgica residual na metade direita da face. Um comprometimento da artéria vertebral, pela 
injeção intramural de Hypaque foi considerado como o mecanismo patogênico mais provável. A complicação registrada é considerada como um argumento a mais para se evitar angiografias da artéria vertebral mediante punção direta deste vaso, devido a suas grandes variações anatômicas.

\section{R E F E R E N C E S}

1. BAKER, A. B. - Cerebrovascular disease: the medullary blood supply and the lateral medullary syndrome. Neurology (Minneapolis) 11:852, 1961.

2. BAKER, H. L. - Incipient strokes. Arteriography: technique and complications. Cerebral vascular disease. Transactions of the Third Conference of Princeton. Grune \& Stratton, New York-London, 1961:26-39.

3. BOYD-WILSON, J. S. - Iatrogenic carotid occlusion: medial dissection complicating arteriography. World Neurol. 3:507, 1962.

4. CURRIER, R. D.; SCHNEIDER, R. C. \& PRESTON, R. E. - Angiographic findings in Wallenberg's lateral medullary syndrome. J. Neurosurg. 19:1058, 1962.

5. DOBRAK, A. H.; BECK, A. L.; MURPHY, T. J. \& ZOLL, J. C. - Cerebral angiography in patients over fifty. Arch. Neurol. (Chicago) 3:582, 1960.

6. EDERLI, A.; SASSAROLI, S. \& SPACCARELLI, G. - Vertebral angiography as a cause of necrosis of the cervical spinal cord. Brit. J. Radiol. 35:261, 1962.

7. HANEY, W. P. \& PRESTON, R. E. - Ocular complications of carotid arteriography in carotid occlusive disease. A report of 3 cases. Arch. Ophtalmol. 67:127, 1962.

8. HOWLAND, W. J. \& CURRY, J. L. - Transient cerebral blindness: "A hazard of vertebral artery catheterization" - Report of four cases. Radiology 83:428, 1964.

9. HELMSOE, L.; TOS, M. - Laryngeal complications of percutaneous ceiebral angiography. Acta Oto-Larying. (Stockolm) 60:175-179, 1965.

10. HOWIESON, J. \& MEGISON, Jr., L. C. - Complication of vertebral artery catheterization. Radiology 91:1109, 1968.

11. JOHNSON, J. H. \& KWISELY, M. H. - Intravascular agglutination of the flowing blood following the injection of radiopaque contrast media. Neurology (Minneapolis) 12:560, 1962.

12. KRAYENBUHL, H. - L'aspect angiographique de la thrombose de l'artère cerebelleuse postérieure et inférieure dans le syndrome de Wallenberg. Neurochirurgie (Paris) 1:45, 1955.

13. KUTT, H.; VEREBELY, K.; BANG, N.; STREULY, F. \& MCDOWELL, F. Possible mechanismas of complications of angiography. Acta radiol. 5:276, 1966.

14. LABAUGE, R.; DUICAILAR, J.; ZHARDEZ, M.; SERRE, L.; CASTAN, P. \& LEFEVRE, F. - Cecité corticale aprés angiographie cerebrale. Reversibilité sous oxygenotherapie hyperbare (à propos de 2 observations). Rev. Neurol. (Paris) 118:283, 1968.

15. LODIN, H. \& OTTANDER, R. G. - Technical puncture complications in carotid angiography. Brit. J. Radiol. 39:782, 1966.

16. MCDOWELL, F. \& KUTT, H. - Complications of angiography. Transaction of the Fourth Conference of Princeton: 18, 1965.

17. OBENCHAIN, T. G.; ClARK, R.; HANAFEE, W. \& WILSON, G. - Complication rate of selective cerebral angiography in infants and children. Radiology 95:669-673, 1970.

18. PESTA, C. M. - Transient cortical blindness: a hazard of veriebral angiography. J. Amer. Osteop. Assoc. 67:290, 1967.

19. PETIT-DUTAILlis, PERTUISET, B.; ROUGENE, J. \& NAMIN, P. - Indications et résultats de l'angiographie vertebrale en neurochirurgie. Presse Med. (Paris) 61:1599, 1953. 
20. PRIBRAM, H. F. N. \& GOUTTES, C. M. - Retinal embolism as a complication of angiography. The possible role of platelet and cholesterol emboli. Neurology (Minneapolis) 15:188, 1965.

21. PRIBRAM, H. F. N. - Compllcations of angiography in cerebro-vascular disease. Radiology 85:33, 1965.

22. RUSSEll, H.; PATTERSON, J.; GOODELl, H. \& DUNNING, H. S. - Complications of carotid angiography. Arch. Neurol. (Chicago) 10:513, 1964.

23. SAHADEVAN, M. G.; RAMAN, P. T. \& PRATAPARAO \& Hoon, R. S. - Lateral medullary ischemia in a young man: report of a case with transient cortical blindness. J. Assoc. Phys. India 17:263, 1969.

24. SCHEINBERG, P. \& ZUNKER, E. - Complication of direct percutaneous carotid arteriography. Arch. Neurol. (Chicago) 8:676, 1963.

25. SCHEINBERG, P. - Practical aspects of complications of angiography. Transaction of the Fourth Conference of Princeton, New York: 27-31, 1965.

26. SHERRICK, J. C. \& AMADOR, L. V. - Cerebral infarction after carotid angiography. Anatomical changes of the brain. Arch. Pathol. 76:133, 1963.

27. SILVERMAN, A. M.; BERGMAN, P. S. \& BENDER, M. B. - The dynamics of transient cerebral blindness - Report of nine episodes following vertebral angiography. Arch. Neurol. (Chicago), 4:333-348, 1961.

28. SUGAR, O.; BUCY, P. C. - Some complications of vertebral angiography. J. Neurosurg. 11:607-615, 1954.

29. VAN LAETHEN, L. \& DOCHEZ, C. - Complication inhabituelle de l'artériographie vértebrale. J. Belge Radiol. 50:229, 1967.

Clínica Neurológica - Hospital do Servidor Público - Rua Pedro de Toledo 1800 - 04039 São Paulo, SP - Brasil. 